\title{
Myeloperoxidase Antibody Measurement
}

National Cancer Institute

\section{Source}

National Cancer Institute. Myeloperoxidase Antibody Measurement. NCI Thesaurus.

Code C92280.

The determination of the amount of myeloperoxidase antibody present in a sample. 